\title{
Labor History at the American Historical Association
}

\author{
Nancy Fitch and Young Sun Hong \\ California State University, Fullerton
}

The 1989 annual meeting of the American Historical Association was characterized by a seemingly small number of panels identifiable as labor history in the traditional sense of the word. One could attribute this phenomenon either to the conservatism of the organization or to what many are beginning to call the "crisis" in labor history, but it was also apparent that scholars are beginning to think about labor in new ways. Some of the change is positive. The impact of gender, the significance of the state and nationality in understanding the formation of the working class, and the cultural and political ideas of ethnic and rural migrants in radical working-class movements are welcome additions to a growing field.

Steve Ross chaired a session on "The Differing Impacts of Economic Transformation: Boston, 1780-1840" which examined the impact of commercial capital on two professions in Boston during the first half of the nineteenth century. Lisa Lubow in a paper on "Winners and Losers, Merchants and Mechanics: The Capitalization of Boston's Building Industry, 1787-1837," adroitly argued that Boston carpenters declined in political and economic importance not because building became a less skilled occupation but because carpenters lost access to capital when larger commercial interests entered the building trades. Carole Srole's paper on "Antebellum Clerk as Mercantile Apprentice: True or False?" demonstrated that in the years before the development of industrial capitalism most people doing clerical work were in large institutions like banks and government offices where their likelihood of becoming proprietors was extremely limited. In the 1830 s and 1840 s clerks began to serve as apprentice merchants and achieve some social mobility, but by this time, employers were already beginning to think of using women as clerical workers. Although both papers focused on what were quintessentially male occupations in this period, Srole suggests that the subsequent feminization of clerical work must be viewed within this historical context. William Rorabaugh was the commentator.

One of the more interesting panels on labor history examined "Mexicans, Migration, and Revolution: Binational Labor Struggles." Chaired by Pedro Castillo, 
the panel included two papers that examined the interrelationship between labor organizing in Mexico and the United States from the 1840s to the present. Devra Weber's paper, "Sin Fronteras: Mexican Migration and Labor Struggles in the United States and Mexico," focused on migrant workers in California, while Emilio Zamora's paper, "De Este y Del Otro Lado, Mexican Labor Struggles along the Border," looked at workers in Texas. Both demonstrated how transnational migration affected politics, labor organizing, and social conflicts on both sides of the border and stressed the impact of the fluidity of people, capital, and the social relations they produced. Prompted by Castillo's fine comments, the session concluded by emphasizing the need to look at labor history from an international perspective, especially in the United States, where the labor force is and has been so diverse in its ethnic origins.

Other sessions focused more on the role of the state in the labor process. The session dealing with the international dimension of the Russian Revolution drew nearly as large an audience as the sessions on the French Revolution. This session on "Radicalism, Nationalism, and the Origins of the Comintern" called for the examination of the little-researched problem of radicalism and nationalism in the non-European periphery of Russia and in the East. Janet Afary presented a paper on "The Debates on Social Democracy and Communism in Iran: 1906-1920"; Geoff Eley addressed the problem of "The Meaning of October: The Bolshevik Revolution, Comintern, and National Revolution"; and Ronald Grigor Suny discussed "National Revolution and Socialist Internationalism: Comintern and the Baku Congress of the East, 1920." Eley's paper suggested that the upsurge of leftwing politics in Europe during 1917-23 in fact led to the realization of reformistdemocratic changes within existing institutional frameworks. In this sense, the institutional changes, and especially the enhancement of the public sphere, signified the completion of the bourgeois-democratic revolution. However, separate revolutionary upheavals on the periphery created the framework for further political conflict as nationality and class competed as organizing principles of political identity. For the first time, anticolonialism emerged at the center of left political discourse. The Stalinist suppression of nationality during the 1930s and the 1940s was not a foregone conclusion in the 1920s.

Ronald Suny examined in detail the Bolshevik language of national-colonial revolution and socialist internationalism within the larger cultural context of the Bolshevik revolutionary euphoria during the 1920 Second World Congress and the subsequent Baku Congress of the Peoples of the East. He also showed how the revolutionary euphoria of 1920 equally contributed to a widespread belief that it would be possible to skip the bourgeois-democratic phase of political and economic development in colonial and semicolonial areas.

In the interesting panel on "Visions and Interests in the Making of the British Welfare State," papers were presented by James Cronin and Peter Weiler on "Uniting Working-Class Interests behind Liberal Policies: Labour and the Welfare State" and by Susan Pederson on "Separate/Unequal: The Subversion of Feminism 
in the Making of the British Welfare State." Cronin and Weiler dealt with Labour party leaders' changing perceptions of the role of the state as a potential instrument of reform, from the prewar years to the late 1930s. Questioning the so-called "working-class strength" model of welfare state development, Cronin and Weiler emphasized instead the prewar hostility among Labour leaders toward state welfare. World War I was a decisive turning point for the reorientation of Labour's attitude to the state. By the end of the war the party had emerged as "a viable contender for power" with a strengthened organization. The Labour party's relatively late arrival at self-confidence in state administration in the late 1930s was achieved only at the price of abandoning those "strategies that gave more scope to mobilization through industrial conflict, to workplace democracy, and to local initiative." Commentator Robert Moeller cautioned Cronin and Weiler about their tendency to equate "working-class interest" with the politics of organized labor and proposed to examine instead "how the war and economic depression mobilized social forces outside Labour's traditional constituencies." Equally important was his question concerning "who constitutes the state," especially "who are civil servants, who sit in the Treasury and other key offices."

Pederson answered many of the questions on gender and family that Cronin and Weiler neglected. Her central thesis was that wartime and postwar corporatism and the integration of male-dominated, organized labor in such politics played a decisive role in marginalizing feminist influences on the making of the welfare state. She warned those who blamed maternalist or social feminists for the genderbiased nature of the welfare state to recall that women were excluded from postwar corporatist politics. Her examples of maintenance allowances to soldiers' and sailors' wives, family allowances, and the Unemployment Insurance Anomalies Act of 1931 illustrated in detail the entrenched norms of the male breadwinner and family wage among male TUC leaders.

If many of these sessions suggest that labor history is becoming a more interesting and exciting area of study, others, especially those related to the French Revolution, indicate that labor seems to be irrelevant to many of the newer themes emerging in contemporary history. The contrast between professional trends in the interpretation of the Revolution and its perceived legacy in modern protest movements from Tiananmin Square to Eastern Europe could not be sharper.

In many parts of the world, such as Brazil, ordinary men and women as well as historians celebrated the bicentennial of the French Revolution in 1989 because they believed that it was a pivotal event in the formation of modern democracies everywhere. None of this spirit of celebration accompanied the many sessions devoted to the French Revolution at the AHA's San Francisco meeting. Instead, like almost every other discussion of the bicentennial, most sessions at the American Historical Association paid homage to revisionist work on the revolution and especially to the recent contributions of Simon Schama and François Furet. Furet argues that his project involves an attempt to rescue Marx from twentieth-century Marxism, but his efforts lead him to conclude that the French Revolution was a 
political, not a social, event. For Furet, "the legacy of the terror poisoned all subsequent revolutionary history." For Schama, the terror was the revolution. It was the source of its energy, and all attempts to write about the revolution as though the terror was incidental to it have failed to understand what the revolution was about. More significant, he proposed that the terror was the first example of modern totalitarianism. Neither Furet nor Schama, then, believe that the legacy of the revolution is modern democracy and republicanism, as reiterated in countless republican histories and celebrated during the revolution's 1889 centennial. Nor do they believe that its legacy lies in the revolution's promise of an egalitarian society, heralded in the long-accepted but now rejected Marxist accounts produced by Georges Lefebvre, Albert Soboul, and Claude Mazauric.

As a consequence, labor history played almost no role in these discussions. As Donald Sutherland argued, the old orthodoxy based on class struggle seems to have declined with the collapse of communism. This may be a positive development if it forces us as historians of the working class to reexamine what we mean by democracy and to pay attention to its limitations in most of modern history. It would be a positive development if we heeded Patrice Higonnet's advice and began to consider the work of feminist scholars of the French Revolution, including that published by Joan Landes, Dorinda Outram, and Lynn Hunt. As Higonnet explained, these historians have examined the process by which misogynist redefinitions of masculine and feminine identity denied women access to the "natural" rights extended to men. Unfortunately, Hunt and Higonnet were the only voices for women present in the many sessions on the revolution. And only the Australians, Peter McPhee and Alison Patrick, seemed to think it was necessary to reiterate the idea that the French Revolution had an important impact on the lives of common people.

\title{
Eleventh Annual North American Labor History Conference
}

\author{
Stanley Shapiro \\ Wayne State University
}

The North American Labor History Conference began its annual meeting on the Wayne State University campus on Thursday, October 19, 1989. As usual, the conference sessions were intriguingly eclectic. They ranged from a look at the Cistercian monasteries of the twelfth century to a Soviet view of the American labor movement in the 1980s. They included papers by scholars from Canada, England, and Sweden; by museum curators, editors, unionists, archivists, and an architect. But of course the brunt of presentations was borne by academicians. 